ISSN 0258-7122

Bangladesh J. Agril. Res. 34(2) : 175-179, June 2009

\title{
STUDY OF HERITABILITY, GENETIC ADVANCE AND VARIABILITY FOR YIELD CONTRIBUTING CHARACTERS IN RICE
}

\author{
RITA BISNE ${ }^{1}$, A. K. SARAWGI ${ }^{2}$ AND S. B. VERULKAR ${ }^{3}$
}

\begin{abstract}
The knowledge of genetic variability in a given crop species for characters under improvement is important in any plant breeding programme. Heritability with genetic advance are more helpful in predicting the gain under effective selection. Genetic parameters for yield and its correspondent characters in rice were estimated from a trial with four CMS lines, eight testers and thirty-two hybrids evaluated for thirteen characters related to yield. Low, moderate, and high genotypic and phenotypic coefficient of variations were observed. High genotypic and phenotypic coefficient of variations were expressed by harvest index, total number of filled spikelets per panicle, 100-grain weight and spikelet fertility percentage. High heritability coupled with high genetic advance was exhibited by harvest index, total number of chaffy spikelets per panicle, grain yield per plant, total number of filled spikelets per panicle and spikelet fertility percentage and selection may be effective for these characters.
\end{abstract}

Key Words: Heritability, variability, genetic advance in rice.

\section{Introduction}

Rice contributes around 45 percent of India's cereal production and is the main staple food for over 60 percent of the population in the country. Despite the age old human concerns about balancing population and food supplies, the world population is expected to continue to grow, possibly reaching 9-11 billion sometimes during 2030-2050. With the current trends of population growth and agricultural production, the demand for food in most parts of world will be double by the year 2025 and nearly triple by 2050 .

The knowledge of genetic variability present in a given crop species for the character under improvement is of paramount importance for the success of any plant breeding programme, Heritability and genetic advance are important selection parameters. Heritability estimates along with genetic advance are normally more helpful in predicting the gain under selection than heritability estimates alone.

\section{Materials and Method}

Four CMS lines having the WA cytoplasmic background viz., IR 68885A, IR 62829A, DRR 2A, and PMS 10A used as lines and eight promising rice varieties viz., BKP 232, R 827-287, Pusa Basmati, R 1060-1674-I-I, R 714-2-103, Culture

1,2\&3 Department of Plant Breeding and Genetics, Indira Gandhi Agricultural University, Raipur (C.G.) 492006, India. 
1001, Super Rice-2 and R 304-24 as testers and thirty-two hybrids were the experimental materials of this study.

All the forty-four genotypes were sown in Randomized Block Design (RBD) with two replications at research farm 1GKVV, Raipur, Chhattisgarh in kharif 2005. A standard spacing of $20 \mathrm{~cm} \times 20 \mathrm{~cm}$ was adopted for planting. Recommended packages of' practices were followed during the crop growth period. Observations were recorded for thirteen characters viz., days to $50 \%$ flowering, plant height $(\mathrm{cm})$, panicle length $(\mathrm{cm})$. effective tillers per plant, total no. of spikelets per panicle, total number of filled spikelets per panicle, total number of chaffy spikelets per panicle, spikelet fertility \%, 100-grain weight (g), harvest index (\%), length of spikelet $(\mathrm{cm})$, breadth of spikelet $(\mathrm{cm})$, and grain yield per plant (g). Genotypic, phenotypic, and environmental variance, heritability and genetic advance were estimated for all thirteen characters.

\section{Results and Discussion}

Variability, heritability and genetic advance was estimated as described here.

\section{Variability}

Low genotypic and phenotypic coefficient of variations were observed for breadth of spikelet, panicle length, length of spikelet, and days to 50 percent flowering. Moderate genotypic and phenotypic coefficient of variations were observed by effective tillers per plant, total number of spikelets per panicle and plant height whereas, high genotypic and phenotypic coefficient of variations were expressed by harvest index, total number of' filled spikelets per panicle, 100-grain weight, and spikelet fertility percentage. High phenotypic variations were composed of high genotypic variations and less of environmental variations, which indicated the presence of high genetic variability for different traits and less influence of environment (Table 1 and 2). Similar results were observed by Kumar et al. (1994), Chaubey and Singh (1994), Pathak and Sharma (1996), Sarvanan and Senthil (1997), Rather et al. (1998), Satya et al (1999), Shivani and Reddy (2000), Iftekharudduala et al. (2001) and Sao (2002).

\section{Heritability}

High heritability were observed for all the characters studied viz., days to 50 percent flowering, plant height, panicle length, effective tillers per plant, total number of filled spikelets per panicle, total number of chaffy spikelets per panicle, total number of spikelets per panicle, spikelet fertility percentage, 100grain weight, harvest index. spikelet length and breadth and grain yield per plant (Table 1 and 2). High heritability indicates the scope of genetic improvement of these characters through selection. Similar results have been reported by Panwar et al. (1997), Sarawgi et al., (2000), Gannamani (2001) and Sao (2002). 
Table 1. Analysis of variance for different characters in rice.

\begin{tabular}{|c|c|c|c|c|c|c|c|c|c|c|c|c|c|c|}
\hline $\begin{array}{l}\text { Source of } \\
\text { variation }\end{array}$ & $\begin{array}{c}\text { Degree } \\
\text { of } \\
\text { freedom }\end{array}$ & $\begin{array}{c}\text { Days to } \\
50 \% \\
\text { flowering }\end{array}$ & $\begin{array}{l}\text { Plant } \\
\text { height } \\
(\mathrm{cm})\end{array}$ & $\begin{array}{c}\text { Panicle } \\
\text { length } \\
(\mathrm{cm})\end{array}$ & \begin{tabular}{|c|} 
Effective \\
tillers/ \\
plant
\end{tabular} & $\begin{array}{c}\text { Total no. } \\
\text { of } \\
\text { spikelets/ } \\
\text { panicle }\end{array}$ & $\begin{array}{c}\text { Total no. } \\
\text { of chaffy } \\
\text { spikelets/ } \\
\text { panicle }\end{array}$ & \begin{tabular}{|c} 
Total no. \\
of filled \\
spikelets/ \\
panicle
\end{tabular} & $\begin{array}{c}\text { 100-grain } \\
\text { wt (g) }\end{array}$ & $\begin{array}{c}\text { Harvest } \\
\text { Index } \\
(\%)\end{array}$ & $\begin{array}{l}\text { Length } \\
\text { of } \\
\text { spikelet } \\
(\mathrm{cm})\end{array}$ & \begin{tabular}{|c} 
Breadth \\
of \\
spikelet \\
$(\mathrm{cm})$
\end{tabular} & $\begin{array}{c}\text { Breadth } \\
\text { of } \\
\text { spikelet } \\
(\mathrm{cm})\end{array}$ & $\begin{array}{l}\text { Grain } \\
\text { yield/ } \\
\text { Plant } \\
\text { (g) }\end{array}$ \\
\hline Replication & 1 & 4.13 & .06 & & & 165.50 & 58.00 & 17.66 & 9.19 & & 42.94 & 0.02 & 0.003 & 49.48 \\
\hline Treatment & 43 & $75.59 *$ & $284.50 *$ & $7.17^{*}$ & $6.20 *$ & 1517.97* & $5767.11^{*}$ & $4284.66^{*}$ & $1982.00 *$ & $0.49 *$ & $561.31 *$ & $0.82 *$ & $0.09 *$ & $168.49 *$ \\
\hline Error & 43 & 0.52 & 1.93 & 0.40 & 1.37 & 363.75 & 166.72 & 171.35 & 20.20 & 0.02 & 13.15 & 0.005 & 0.003 & 5.72 \\
\hline
\end{tabular}

*= Significance at $\mathrm{p}=0.05$ level

Table 2. Genotypic and phenotypic coefficient of variability (gcv and pvc), heritability $\left(\mathrm{h}^{2}\right)$, genetic advance and components of variance for different characters in rice.

\begin{tabular}{|c|c|c|c|c|c|c|c|c|c|c|c|c|c|}
\hline & $\begin{array}{c}\text { Days to } \\
50 \% \\
\text { flowering }\end{array}$ & $\begin{array}{l}\text { Plant } \\
\text { height } \\
(\mathrm{cm})\end{array}$ & $\begin{array}{l}\text { Panicle } \\
\text { length } \\
(\mathrm{cm})\end{array}$ & $\begin{array}{l}\text { Effective } \\
\text { tillers/plant }\end{array}$ & $\begin{array}{c}\text { Total no. } \\
\text { of } \\
\text { spikelets/ } \\
\text { panicle }\end{array}$ & $\begin{array}{c}\text { Total no. } \\
\text { of filled } \\
\text { spikelets/ } \\
\text { panicle }\end{array}$ & $\begin{array}{c}\text { Total no. } \\
\text { of chaffy } \\
\text { spikelets/ } \\
\text { panicle }\end{array}$ & $\begin{array}{c}\text { Spikelet } \\
\text { fertility } \\
\text { (\%) }\end{array}$ & \begin{tabular}{|c}
$100-$ \\
grain \\
wt \\
$(\mathrm{g})$ \\
\end{tabular} & $\begin{array}{c}\text { Harvest } \\
\text { Index } \\
(\mathrm{HI})\end{array}$ & \begin{tabular}{|l}
$\begin{array}{c}\text { Length } \\
\text { of } \\
\text { spikelet } \\
(\mathrm{cm})\end{array}$ \\
\end{tabular} & $\begin{array}{c}\text { Breadth } \\
\text { of } \\
\text { spikelet } \\
\text { (cm) }\end{array}$ & $\begin{array}{c}\text { Grain } \\
\text { yield/ } \\
\text { Plant } \\
\text { (g) }\end{array}$ \\
\hline PCV \% & 6.36 & 13.03 & 8.09 & 22.45 & 19.02 & 60.63 & 66.10 & 57.64 & 30.72 & 69.09 & 7.16 & 9.13 & 62.80 \\
\hline $\begin{array}{l}\text { Heritability \% } \\
\text { (Broad base) }\end{array}$ & 98.60 & 98.70 & 89.40 & 63.90 & 61.30 & 94.40 & 92.30 & 98.00 & 93.00 & 95.40 & 98.70 & 93.10 & 93.40 \\
\hline $\begin{array}{l}\text { Genotypic } \\
\text { variance }\left(\sigma^{2} g\right)\end{array}$ & 37.54 & 141.29 & 3.39 & 2.42 & 577.11 & 2800.20 & 2056.66 & 980.90 & 0.24 & 274.08 & 0.41 & 0.04 & 81.39 \\
\hline $\begin{array}{l}\text { Phenotypic } \\
\text { variance }\left(\sigma^{2} p\right)\end{array}$ & 38.06 & 143.22 & 3.79 & 3.79 & 940.86 & 2962.92 & 2228.01 & 1001.10 & 0.26 & 287.23 & 0.42 & 0.043 & 87.77 \\
\hline
\end{tabular}




\section{Genetic advance}

High genetic advance was exhibited by harvest index, total number of chaffy spikelets per panicle, grain yield per plant, total number of filled spikelets per panicle, and spikelet fertility percentage. Moderate genetic advance were observed for days to 50 percent flowering, panicle length, length of paddy, and breadth of paddy (Table 1 and 2). Similar findings were also reported by Regina et al. (1994), Vanniarajan et al. (1996), Shivani and Reddy (2000), Iftekharuddaula et al. (2001), Gannamani (2001) and Sao (2002)

High heritability with high genetic advance indicates the control of additive gene and selection may be effective for those characters.

\section{References}

Chaudhary, P. K. and R. P. Singh 1994. Genetic variability, correlation and path analysis of yield components of rice. Madras Agric. J. 81(9):468-470

Gannamani, N. 2001. Study of heterosis and combining ability by utilizing cytoplasmic genetic male sterility and fertility restoration system in rice (Oryza sativa L., M. Sc. (Ag.) Thesis, GAU, Raipur.

Iftekharuddaula, K. M. M. S. Hassan, M. J. Islam, M. A. Badshah, M R Islam, and K. Akhter 2001. Genetic evaluation and selection criteria of hybrids rice in irrigated ecosystem of Bangladesh. Pakistan J. Biological Sci. 4(7): 790-792

Kumar, R, Krishnapal, S. K. Mandal, S. C. Ramashankar Prasad, and R Rai 1994. Genetic study of major characters in upland rice. Env. and Ecology. 12(2): 363-365.

Panwar, Ashvani, R. P. S. R. K. Sharma, K. P. S. Arya, and A Panwar 1997. Genetic variability and inter-relationship in rice (Oryza sativa L.). Adv. Plant Sci. 10(1): 29-32.

Pathak, P. K. and K. K. Sharma 1996. Variability and correlation among physical quality characters of Joha rice of Assam. J. Agric. Sci. Soc. North-East India 9(1) 18- 22.

Rather, A. G., G. N. Mir and F. A. Sheikh 1998. Genetic parameters for some quantitative traits in rice. Adv. in Plant Sci. 19(2)163-166.

Regina, A, N. R. Bai, R. Devika, and C. A. Joseph 1994. Genetic variability and correlation in short duration rice cultivars. J. Tropical Agric. 32(2): 11 8-120

Sao, A. 2002. Studies on combining ability and heterosis in $F_{1}$ rice hybrids using cytoplasmic male sterile lines. M. Sc. (Ag.) Thesis, IGAU, Raipur.

Sarawgi, A. K., N. K. Rastogi, and D. K. Soni. 2000. Studies on some quality parameters of indigenous rice in Madhya Pradesh. Ann. Agric. Res. 21(2): 258-261.

Sarvanan, R. and N. Senthil. 1997. Genotypic and phenotypic variability, heritability and genetic advance in some important traits in rice. Madras. Agric. J. 84(5): 276- 277.

Satya, A., G. Kandasamy, and J. Ramalingam. 1999. Heterosis in hybrid rice. Crop Res Hisar 18(2) 243-246. 
Shivani, D. and N. Sree Rama Reddy. 2000. Variability, heritability and genetic advance for morphological and physiological traits in certain rice hybrids. Oryza 37(3):231-233.

Vanniarajan, C., P. Rangasamy, J. Ramalingam, N. Nadarajan, and Arumugampillai. 1996. Studies on genetic variability in hybrid rice derivatives. Crop Res. 12(1):24-27. 